\title{
Effect of prescribed fire on soil properties and soil erosion in a Mediterranean mountain area
}

\author{
Felícia Fonseca*, Tomás de Figueiredo, Clotilde Nogueira, Anabela Queirós \\ CIMO - Centro de Investigação de Montanha, Escola Superior Agrária, Instituto Politécnico de Bragança, Campus de Santa Apolónia, $5300-253$ Bragança, Portugal
}

\section{A R T I C L E I N F O}

Handling Editor: Yvan Capowiez

Keywords:

Shrubs

Chemical soil properties

Runoff

Soil loss

Permeability

\begin{abstract}
A B S T R A C T
Prescribed fires are a common management practice in the Mediterranean region and can be an alternative to reduce the quantity of fuel and hence decrease the wildfire risk. This research focused in effects of a prescribed fire, which was applied in Montesinho Natural Park (PNM), in soil properties and on soil erosion processes. Chemical soil properties were assessed before, two, six and thirty-six months after the fire. Despite low fire intensity, soil chemical changes were observed. Thirty-six months after the fire it turned out that the soil organic matter, $\mathrm{pH}$ values and electrical conductivity were similar to those seen before the fire. However, the same was not verified with the values of the exchangeable bases, extractable potassium and phosphorus and exchangeable acidity that differ from the observed ones before the fire. Runoff and soil loss were monitored in a set of $4 \mathrm{~m}^{2}$ paired plots installed in the study area, during 14 months after the fire and summed annual losses equivalent to $10.3 \mathrm{~mm}$ runoff and $1.3 \mathrm{Mg} \mathrm{ha}^{-1}$ soil loss. Although corresponding to a short monitoring period, these results may add to a better knowledge of the potential susceptibility of burnt shrublands to soil degradation and their natural recovery rates.
\end{abstract}

\section{Introduction}

Large areas of shrublands and forests are destroyed by fire every year in the Mediterranean region, where wildfires are a most relevant environmental problem; nevertheless, in the ecological context of the Mediterranean mountains, fire is part of the vegetation and landscapes dynamics (IPB/ICN, 2007; Pausas et al., 2008). However, previous studies carried out in Mediterranean ecosystems highlight a wide variability fire effects on soil properties and hydrological processes (e.g., Certini, 2005; Bento-Gonçalves et al., 2012; Inbar et al., 2014; Alcañiz et al., 2016), contributing to soil degradation.

The use of prescribed fire, after careful planning and under controlled conditions, is one of the most important measures to prevent the occurrence of high intensity fires (Fernandes and Botelho, 2004; BentoGonçalves et al., 2012). There are many reasons to apply prescribed fire in forest management as, for instance, it reduces hazardous fuels and breaks up fuel continuity (Fernandes and Botelho, 2004; Fernandes and Loureiro, 2010), it prepares sites for seeding or planting of forest species, and controls the competing vegetation (Brooks and Lusk, 2009), it improves habitat and creates diversity needed by wildlife (Wasserman, 2015), it controls insects and diseases (Parker et al., 2006), it improves pasture quality for cattle (Fonseca et al., 2011), it improves access into forest stands, and it contributes to preserve fire-dependent plant species, particularly important in Mediterranean environments (Pausas and Keeley, 2009). Prescribed fire in shrublands applied to protect forests stands is a relatively common practice in Montesinho Natural Park (PNM), Northeast Portugal (IPB/ICN, 2007; Fonseca et al., 2011). Soil is a qualitatively scarce resource in this region and even more scarce in the marginal areas where the shrubs dominate (Figueiredo, 2002). The protection of this resource is essential due to its key role in ecosystem services provision, associated to the hydrological cycle, nutrient cycles and carbon dynamics and storage (Rashid, 1987; Thomas et al., 1999; Pardini et al., 2004; Bompastor et al., 2009; José, 2009; Fonseca et al., 2011; Fonseca et al., 2012). The knowledge of soil degradation processes and the context factors that determine them is a basic condition for the design of strategies, actions and practices focused in the soil resource protection.

During burning, plant cover and litter layers are consumed, and the mineral soil is heated, resulting in changes in physical, chemical, mineralogical, and biological soil properties (Hubbert et al., 2006). The combination of combustion and heat transfer produces sharp temperature gradients in the topsoil profile (Certini, 2005). The extent and duration of fire effects on soil properties depend on fire behaviour, especially related to fire severity, as well as on post-fire weather conditions, mainly the characteristics of subsequent rainfall events (de Luís et al., 2001; Certini, 2005; Francos et al., 2016). A direct effect of fire

\footnotetext{
* Corresponding author.

E-mail address: ffonseca@ipb.pt (F. Fonseca).
} 
on soil surface is the formation of a continuous water-repellent film, which reduces permeability and increases runoff (Imeson et al., 1992). In Mediterranean ecosystems, where the torrential rainfall events are frequent in autumn and winter, October to March is a critical period when soil susceptibility to water erosion processes is increased after the summer wildfires (Andreu et al., 2001; Fonseca et al., 2011; Francos et al., 2016). Higher frequency of fire and intense rainfalls represents a large potential to reduce soil fertility by erosion and nutrient loss, therefore limiting burnt areas recovery and enhancing soil degradation (Thomas et al., 1999).

The effect of fire on soil organic matter content is widely variable, and depends on several factors including fire type, intensity and duration, and even land slope (González-Pérez et al., 2004; Shakesby, 2011). Depending on fire severity, the organic matter can suffer slight distillation, charring, or complete oxidation (Certini, 2005). Fire induces changes in nutrient cycles (Certini, 2005) and the majority of those nutrients released to the soil by burned vegetation are in highly soluble forms, with the exception of soil phosphorus, which increases insolubility after fire. In summary, fires cause changes on soil physical and chemical properties that, in turn, affect soil water permeability, rainwater intake rate, life forms support capacity and resistance to erosion and leaching processes.

This study aimed at evaluating the impact of a prescribed fire in a mountain scrubland area, applied to protect neighbouring pine forest stands, on topsoil properties $(0-20 \mathrm{~cm})$ and on hydrological processes, as runoff and soil loss.

\section{Methods}

Montesinho Natural Park (PNM) is a protected area in the northeast of Portugal, covering an area of $750 \mathrm{~km}^{2}$, one third of which corresponds to shrub communities. The present study was carried out, in an area covered by shrubs $\left(41^{\circ} 53^{\prime} 57.06^{\prime \prime} \mathrm{N}, 6^{\circ} 40^{\prime} 55.39^{\prime \prime} \mathrm{W}\right)$, located within a state ruled forest perimeter in PNM, which was subject to prescribed fire according to its management plan (Fig. 1). It is a plateau area, $800 \mathrm{~m}$ asl, cut by deep valleys, with $12{ }^{\circ} \mathrm{C}$ mean annual temperature and around $850 \mathrm{~mm}$ mean annual rainfall, concentrated from October to March (Agroconsultores and Coba, 1991). Soils are schist derived Umbric Leptosols, stony with medium-texture, acid and with medium/ high organic matter content in the surface layer (FAO/UNESCO, 1988;
Agroconsultores and Coba, 1991).

The study area was formerly occupied by Pinus pinaster species, but on August 1998 a wildfire destroyed part of the forest stand. Since then, shrub vegetation invaded the area and in 31 March of 2011 a prescribed fire was applied to 5 ha shrubland, as part of the management plan of the pine forest plots, in order to control shrub vegetation and reduce fire hazard in the remainder forest. A survey of the vegetation was carried out before the prescribed fire, identifying patches with clear dominance of species representative of the PNM shrub communities (IPB/ICN, 2007; Bompastor et al., 2009). The relative abundance of these species was evaluated in 11 sites randomly distributed in the area to be burned. Accordingly, prior to prescribed fire, the area was covered by Erica australis (44\% of the surface), Chaemespartium tridentatum (30\%), Cystus ladanifer (26\%). The prescribed fire differently affected individuals of the three species, the former showing a high resistance to fire.

During prescribed fire, temperatures at surface and at $5 \mathrm{~cm}$ below ground were measured immediately after the fire with a portable infrared apparatus as shown in Fig. 2. These data, together with observations of the incompletely burned vegetation and the degree of litter consumption, allowed a qualitative evaluation of fire severity, concluding that it was a low severity fire (Hungerford, 1996).

In the same above mentioned 11 sites where the shrub vegetation inventory was carried out, disturbed soil samples were collected before prescribed fire (BF), two $(2 \mathrm{M})$, six $(6 \mathrm{M})$ and thirty-six months $(36 \mathrm{M})$ after fire, at $0-5,5-10$ and $10-20 \mathrm{~cm}$ depths, to assess organic matter, nutrients concentration, soil $\mathrm{pH}$ and electrical conductivity. Methods applied in laboratory analysis comprised the Walkley-Black method for soil organic matter, the Egner-Riehm method for extractable phosphorus and potassium, the method proposed by Jones (2001) for electrical conductivity, and $\mathrm{pH}$ determination in a soil-water suspension (1:2.5 soil water ratio). Exchangeable bases were determined by atomic adsorption $\left(\mathrm{Ca}^{2+}\right.$ and $\left.\mathrm{Mg}^{2+}\right)$ and by flame emission spectrophotometry $\left(\mathrm{K}^{+}\right.$and $\left.\mathrm{Na}^{+}\right)$. Cation exchangeable capacity was calculated as the sum of exchangeable bases and exchangeable acidity.

Permeability was measured on 11 undisturbed samples randomly collected in $100 \mathrm{~cm}^{3}$ cylinders in the surface layer $(0-5 \mathrm{~cm})$, at several moments: before the prescribed fire, soon after fire, and two and eight months after fire. The permeability was measured in a constant head closed circuit laboratory permeameter.
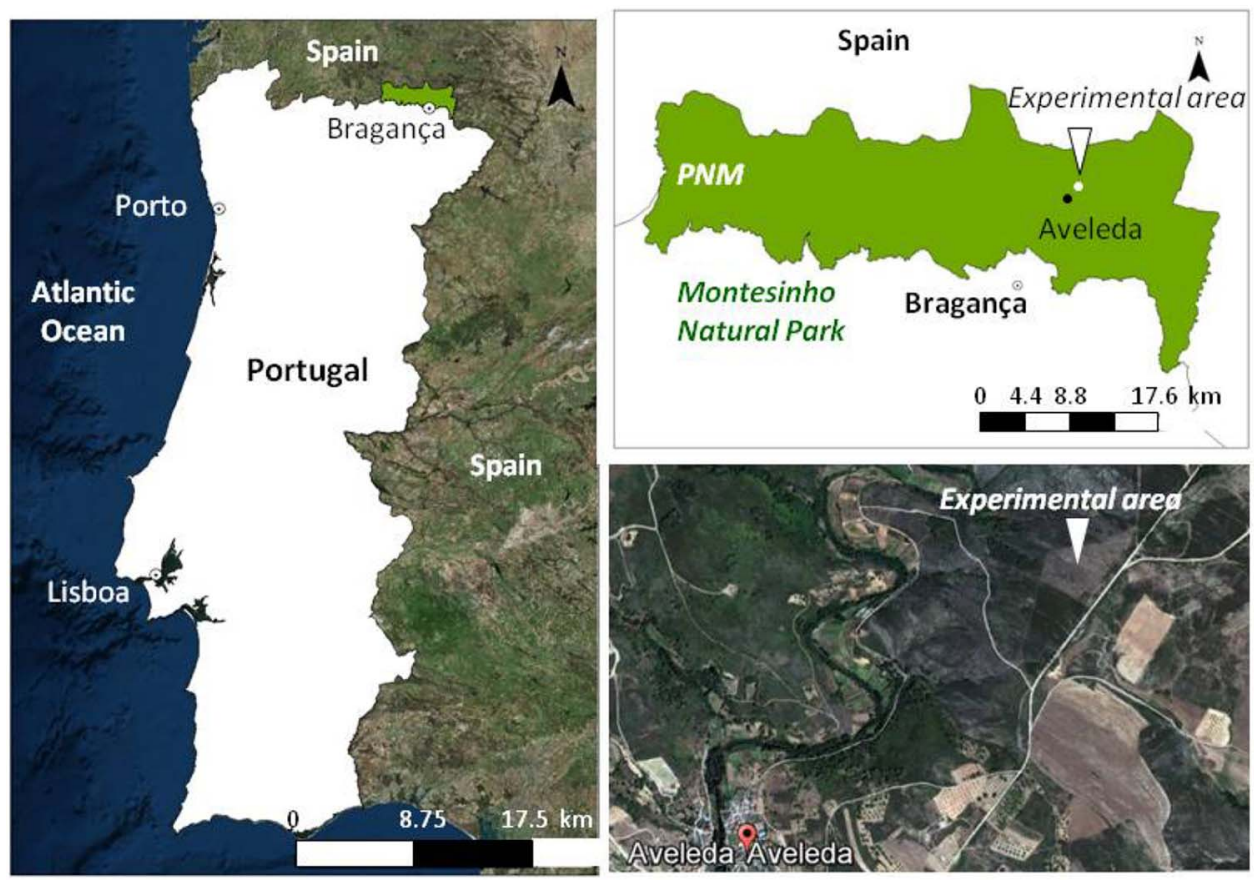

Fig. 1. Location of the study area in Montesinho Natural Park (PNM), NE Portugal.

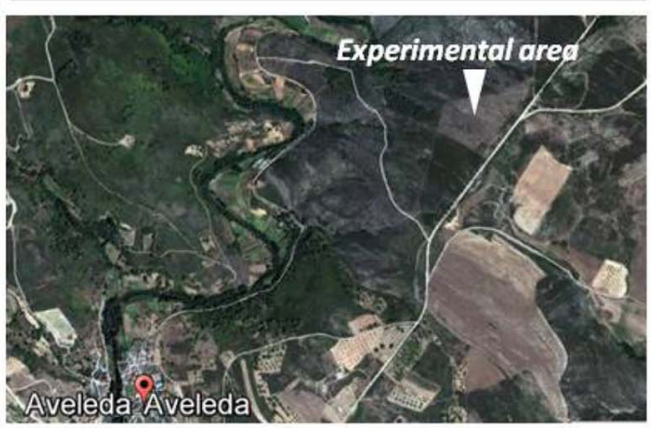




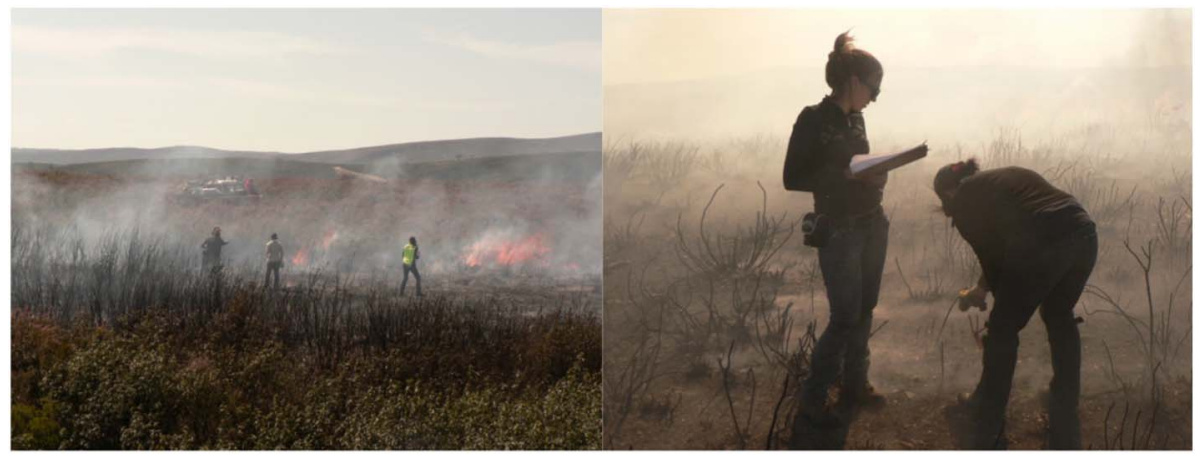

Fig. 2. Observations of vegetation consumption and temperature measurement on surface and $5 \mathrm{~cm}$ below after passage of prescribed fire.

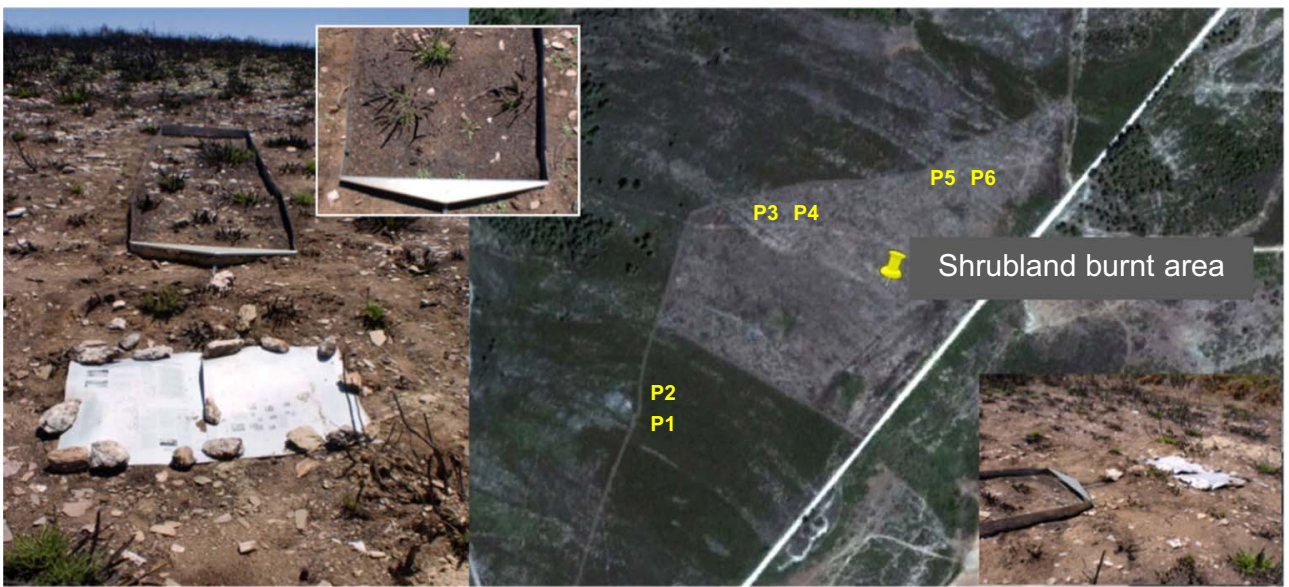

Fig. 3. Experimental device to measure water erosion in the burned area: location of the 6 microplots (right center), microplots configuration to collect runoff and sediment (left and right), microplots surface condition after installation (center, left, right).

Following current methodology and field and lab procedures (Figueiredo et al., 2012), a set of 6 paired erosion microplots (4 m long $\times 1 \mathrm{~m}$ wide, mean slope $8 \%$ ) was installed in the study area, two days after the prescribed fire (Fig. 3). Erosion microplots were bounded upwards and laterally by metal plates and in their lower part by a triangular metal gutter, provided with a hole. Through this, water and sediment exported from the plot area were conveyed by a flexible hose into a $10 \mathrm{~L}$ plastic tank, placed downslope in a pit, excavated for this purpose. Water and sediment exported from microplots were collected after each period of precipitation, 8 in total during 14 months (April 2011 to May 2012). Outdoor operations comprised collecting sediment trapped on microplot gutter and replacing filled tanks by empty and clean ones. Indoor operations included oven-drying $\left(105^{\circ} \mathrm{C}\right)$ and weighting sediment collected on microplot gutter, measuring tank water volume with a graduated bucket, and sampling after thorough stirring of water in the bucket, with a $100 \mathrm{ml}$ beaker, oven-dried afterwards for sediment dry-mass determination. Runoff was calculated from measured water volume and soil loss from sediment concentration in runoff water volume plus the mass of sediment collected in the gutter, divided in both cases by microplot area (runoff expressed in $\mathrm{mm}$ equivalent height, soil loss expressed in $\mathrm{g} \mathrm{m}^{-2}$ ). Some erosion response indicators were also calculated, including runoff coefficient (ratio between runoff and precipitation, \%), sediment concentration in runoff (ratio between soil loss and runoff, $\mathrm{g} \mathrm{L}^{-1}$ ) and unit soil loss (ratio between soil loss and precipitation, $\mathrm{g} \mathrm{m}^{-2} \mathrm{~mm}^{-1}$ ).

A pluviometer, installed in the study area, allowed the measurement of total precipitation between each one of the 8 runoff and soil loss collection dates. During the first two years of the experiment, when the assessment of soil erosion processes has been carried out (April 2011 to May 2012), the precipitation was abnormally low (about $40 \%$ of the average for the region), with a summer wetter and a winter drier than the normal seasonal rainfall distribution (Fig. 4) (IPMA (Instituto Português do Mar e da Atmosfera), 2016).
As required, the experiment was designed to comply with the research objectives stated above. Seasonal variations in soil properties and hydrological processes in unburned areas may be assumed negligible when compared with the direct and indirect effects of fire, because fire induces sharp direct changes in vegetation and litter cover, which leave surface exposed to erosion and affect processes in soils and ecosystems. As so, the experiment was installed and developed only in the burned area with no unburned control plots. This way, with the prefire conditions fully characterized and taken as reference, the experiment provided the information required to meet the research objectives, meaning the study of the temporal evolution of topsoil properties and soil and water losses due to erosion, in an area burned by prescribed fire.

The statistical treatment of the information collected included descriptive statistics, analysis of variance (one-way) and tests of means comparison (Tukey, $\mathrm{p}<0.05$ ).

\section{Results}

The temporal variation patterns of soil organic matter content (SOM) are similar at all depths (Fig. 5). Six months after the prescribed fire, SOM showed a non-significant decrease in the three sampled layers ( $<10 \%$ of pre-fire value). Thirty-six months after the fire, at the three depths, SOM average values were higher than those of the reference situation (BF), with a relative increase of $8 \%$ in the uppermost layers and of about $20 \%$ in the deepest layer, in both representing a not statistically significant change.

Extractable phosphorus and potassium showed different behaviour. Extractable phosphorus increased in all layers six months after the fire when compared to the reference situation (BF), showing a slight decrease thirty-six months after fire, yet with values always higher than the ones observed before the fire (Fig. 5). In the surface layer $(0-5 \mathrm{~cm})$ the phosphorus contents are similar in all sampling dates, the other 


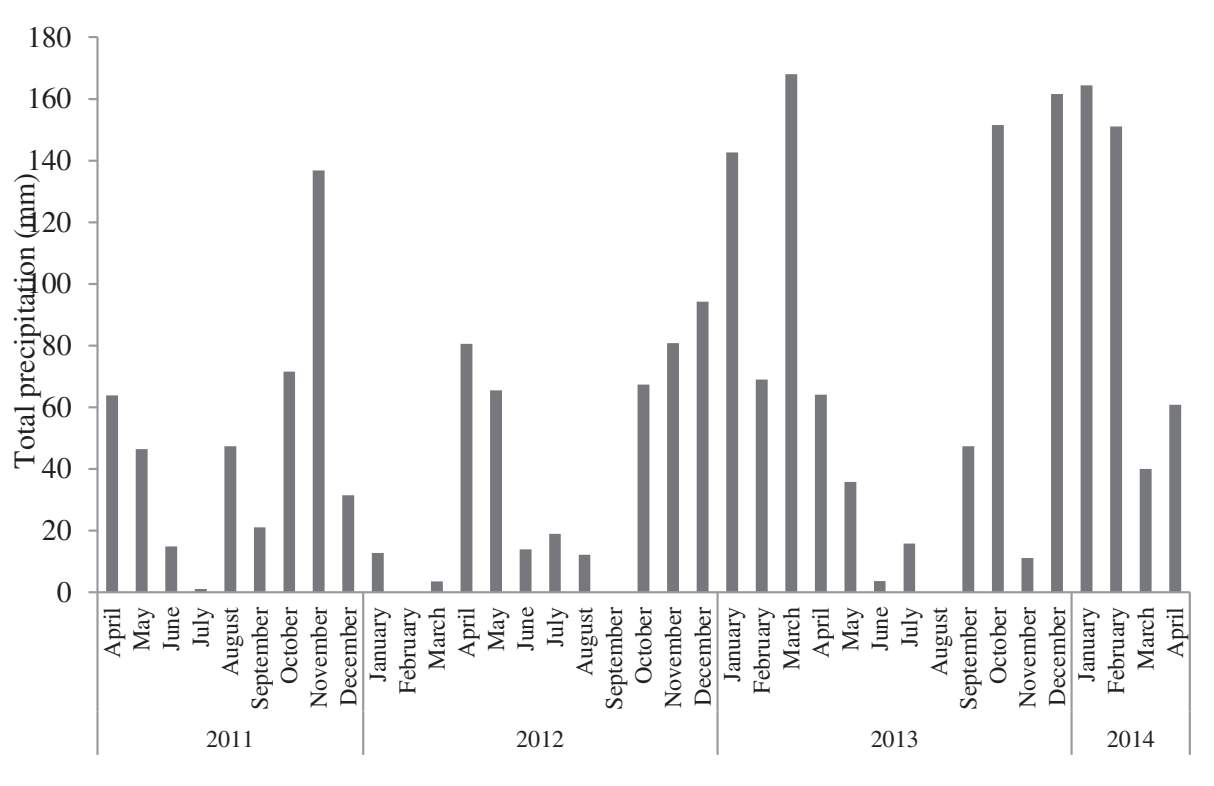

layers presenting significant differences over time: the first two sampling dates (BF and $2 \mathrm{M}$ ) with lower values than the last two (6M and 36M). For extractable potassium (Fig. 5), the reference situation (BF) and that thirty-six months after the fire, showed similar values in each sampled layer. However, two and six months after the fire, the potassium contents were significantly lower than the remainder sampling dates.

Results concerning soil exchangeable complex as affected by fire are presented in Table 1. Thirty-six months after the fire, sum of exchangeable bases (SEB) decreased significantly in deeper layers (5-10 cm, about $50 \%$ and $10-20 \mathrm{~cm}$, about $55 \%$ ), as compared to the $\mathrm{BF}$, while in the surface layer values were similar to those BF. At the three sampling depths, the values of base cations in the original situation (BF) follow the sequence $\mathrm{Ca}^{2+}>\mathrm{Mg}^{2+}>\mathrm{K}^{+}>\mathrm{Na}^{+}$, a pattern that remains at the remainder sampling dates, except six months after fire. Calcium is the most important base cation in the soil, contributing for around $70 \%$ of the sum of exchangeable bases until six months after the fire, decreasing to about $55 \%$ at the end of the thirtysix months. In general, exchangeable acidity (EA) increases in depth, following closely the variations of the exchangeable aluminum, a change that is reflected in the corresponding decrease in base saturation (BS). Thirty-six months after the fire, the exchangeable acidity presents, in all layers, considerably higher values than the reference situation. Increases of about 60,85 and $88 \%$ were observed in the layers $0-5$, 5-10 and 10-20 cm, respectively. Cation exchangeable capacity (CEC) showed very similar values at all sampling dates in each layer.

In each depth, the mean values of $\mathrm{pH}$ before the fire and thirty-six months after were not significantly different, but these values are significantly higher two and six months after the fire (Fig. 5). Overall, the electrical conductivity values (EC) decreased in all depths after the fire, but without significant differences as compared to $\mathrm{BF}$, reaching the lowest values thirty-six months after the fire (Fig. 5).

A brief summary of the changes in chemical soil properties at several sampling dates after fire is presented in Table 2. Most chemical soil properties studied had fluctuations within the experimental time span. The last sampling date was taken as a time reference for evaluating global recovery of the original pre-fire condition, in what regards soil chemical properties. In fact, after thirty-six months the effects of prescribed fire are still visible in extractable potassium, base cations (Ca and $\mathrm{Mg}$ ), sum of exchangeable bases and base saturation, generally with values significantly lower than the pre-fire situation. In contrast, extractable phosphorus, exchangeable aluminum and exchangeable acidity show values significantly higher than BF. However, soil surface
Fig. 4. Precipitation values, recorded at the Bragança weather station, from April 2011 to April 2014. layer $(0-5 \mathrm{~cm})$, had a faster recovery when compared to deeper layers (5-10 and $10-20 \mathrm{~cm})$.

In addition to the effects produced in soil chemical properties, fire can alter the hydraulic properties of soil, as well as runoff and soil loss. A total of $545.3 \mathrm{~mm}$ of precipitation was recorded during 14 months following the fire (evaluation period of runoff and soil loss), with a total runoff and soil loss the $13 \mathrm{~mm}$ and $147.3 \mathrm{~g} \mathrm{~m}^{-2}$, respectively. The overall erosive response in this period resulted in a runoff coefficient of $2.4 \%$, with a sediment concentration of $11 \mathrm{~g} \mathrm{~L}^{-1}$ and soil loss per unit of precipitation of $0.27 \mathrm{~g} \mathrm{~m}^{-2} \mathrm{~mm}^{-1}$ (Table 3). In parameters, runoff and soil loss, significant differences were observed between collects, as a result of a temporal variation in the erosive response of the microplots. The average pattern of this response is shown in Fig. 6. Runoff and soil loss differ clearly in this pattern, in the first case approaching the linear response, with a strong correlation between the cumulative values of precipitation and runoff $\left(\mathrm{r}^{2}=0.954\right)$. In spite of this, two periods were observed in which the erosive response was more productive in terms of water and sediment exportation. The pattern resembles a sigmoid curve, with soil losses tendentially smaller over time.

Soil permeability, in average terms, was included in the classes high and very high. However, the values of this parameter showed a very pronounced dispersion. It should be noted that the median values are noticeably lower than the mean values, still indicating non-unfavorable surface water flow conditions in most samples. The mean permeability values evolved over time, decreasing from $22 \mathrm{~cm} \mathrm{~h}^{-1}$ in the original soil condition to $14 \mathrm{~cm} \mathrm{~h}^{-1}$ immediately after fire. Two months later, the mean increased significantly to $113 \mathrm{~cm} \mathrm{~h}^{-1}$, decreasing to $36 \mathrm{~cm} \mathrm{~h}^{-1}$ eight months after fire, a value that differs significantly from the remainder ones (Table 4).

\section{Discussion}

After the prescribed fire no significant changes were observed in SOM for as long as thirty-six months, which is in agreement with the low severity fire applied and its actual low impact. However, thirty- six months after the fire, SOM was slightly higher than that before the fire. The observed changes in SOM contents can be accommodated within the known and justified oscillations that occur throughout the year, mainly due to variations in soil temperature and moisture and their effects in soil biological activity, which is related to the decomposition rates of soil organic materials. Scharenbroch et al. (2012) refer that one year after a low severity prescribed fire the soil organic carbon increased, suggesting that the soil did not reach such a high temperature 
$\operatorname{SOM}\left(\mathrm{g} \mathrm{kg}^{-1}\right)$

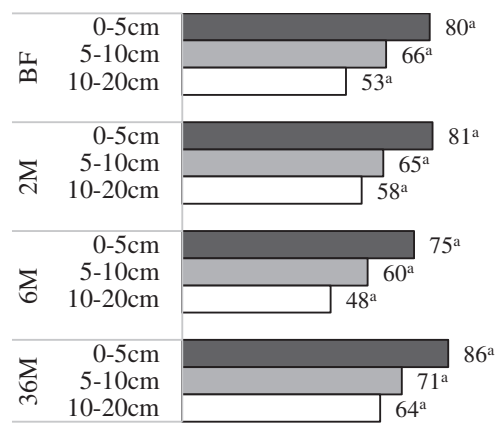

Potassium ( $\left.\mathrm{mg} \mathrm{kg}^{-1}\right)$

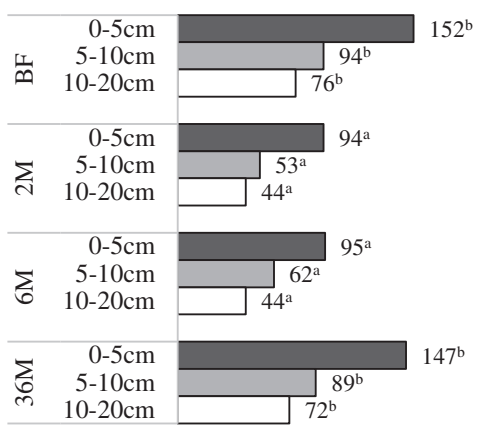

Electrical condutivity $(\mu \mathrm{S})$

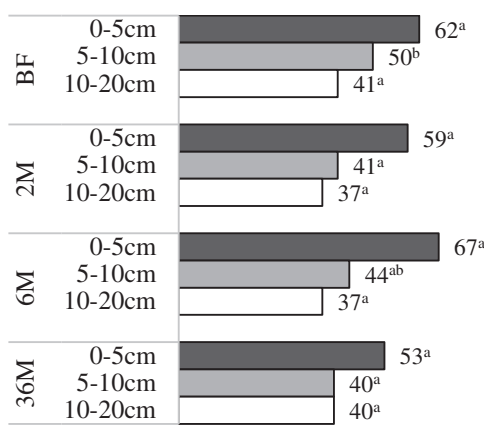

Phosphorus (mg kg-1)

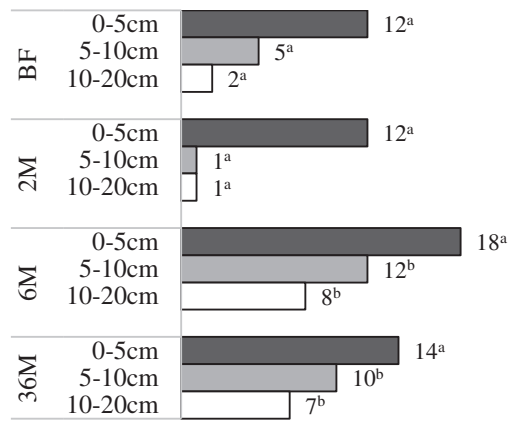

$\mathrm{pH}\left(\mathrm{H}_{2} \mathrm{O}\right)$

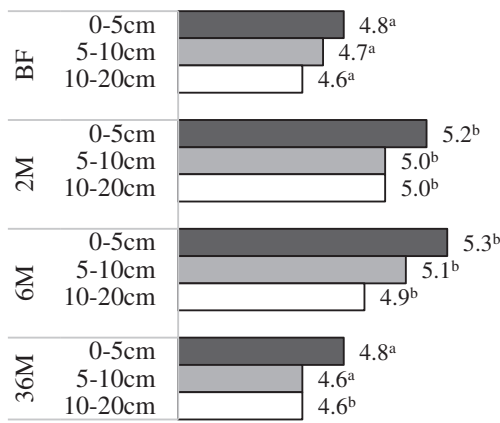

Fig. 5. Mean values of selected soil chemical properties per soil layer for each sampling date: Before the fire (BF), two (2 M), six (6 M) and thirty-six (36) months after fire. In bars with the same colour means followed by different letters are significantly different $(\mathrm{p}<0.05)$.

\section{Table 1}

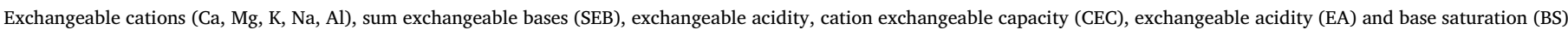

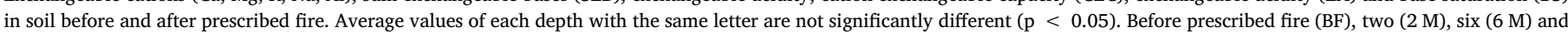
thirty-six (36 M) months after prescribed fire.

\begin{tabular}{|c|c|c|c|c|c|c|c|c|c|c|}
\hline Depth & Sampling & $\mathrm{Ca}^{2+}$ & $\mathrm{Mg}^{2+}$ & $\mathrm{K}^{+}$ & $\mathrm{Na}^{+}$ & $\mathrm{Al}^{3+}$ & SEB & EA & CEC & BS \\
\hline$(\mathrm{cm})$ & date & $(\mathrm{cmol}$ & & & & & & & & (\% CEC) \\
\hline \multirow[t]{4}{*}{$0-5$} & $\mathrm{BF}$ & $3.37^{\mathrm{a}}$ & $0.77^{\mathrm{a}}$ & $0.35^{\mathrm{a}}$ & $0.12^{\mathrm{a}}$ & $0.72^{\mathrm{a}}$ & $4.61^{a}$ & $1.33^{\mathrm{a}}$ & $5.9^{\mathrm{a}}$ & $77^{\mathrm{b}}$ \\
\hline & $2 \mathrm{M}$ & $3.00^{\mathrm{a}}$ & $0.71^{\mathrm{a}}$ & $0.29^{\mathrm{a}}$ & $0.08^{\mathrm{a}}$ & $1.18^{\mathrm{b}}$ & $4.08^{\mathrm{a}}$ & $1.53^{\mathrm{a}}$ & $5.6^{\mathrm{a}}$ & $72^{b}$ \\
\hline & $6 \mathrm{M}$ & $3.07^{\mathrm{a}}$ & $0.60^{\mathrm{a}}$ & $0.55^{\mathrm{a}}$ & $0.12^{\mathrm{a}}$ & $1.04^{\mathrm{ab}}$ & $4.34^{\mathrm{a}}$ & $1.13^{\mathrm{a}}$ & $5.5^{\mathrm{a}}$ & $78^{b}$ \\
\hline & $36 \mathrm{M}$ & $2.32^{\mathrm{a}}$ & $0.61^{\mathrm{a}}$ & $0.34^{\mathrm{a}}$ & $0.12^{\mathrm{a}}$ & $1.68^{\mathrm{c}}$ & $3,39^{a}$ & $2.11^{\mathrm{b}}$ & $5.5^{\mathrm{a}}$ & $58^{\mathrm{a}}$ \\
\hline \multirow[t]{4}{*}{$5-10$} & $\mathrm{BF}$ & $1.89^{c}$ & $0.40^{\mathrm{b}}$ & $0.21^{\mathrm{a}}$ & $0.11^{\mathrm{ab}}$ & $0.96^{\mathrm{a}}$ & $2.61^{\mathrm{b}}$ & $1.55^{\mathrm{a}}$ & $4.2^{\mathrm{a}}$ & $62^{c}$ \\
\hline & $2 \mathrm{M}$ & $1.46^{\mathrm{b}}$ & $0.28^{\mathrm{a}}$ & $0.19^{\mathrm{a}}$ & $0.08^{\mathrm{a}}$ & $1.60^{\mathrm{b}}$ & $2.01^{\mathrm{b}}$ & $1.97^{\mathrm{a}}$ & $4.0^{\mathrm{a}}$ & $51^{b}$ \\
\hline & $6 \mathrm{M}$ & $1.88^{\mathrm{c}}$ & $0.30^{\mathrm{ab}}$ & $0.51^{\mathrm{b}}$ & $0.14^{\mathrm{b}}$ & $1.59^{\mathrm{b}}$ & $2.83^{\mathrm{b}}$ & $1.63^{\mathrm{a}}$ & $4.5^{\mathrm{a}}$ & $63^{c}$ \\
\hline & $36 \mathrm{M}$ & $0.77^{\mathrm{a}}$ & $0.28^{\mathrm{a}}$ & $0.19^{\mathrm{a}}$ & $0.10^{\mathrm{ab}}$ & $2.31^{\mathrm{c}}$ & $1.34^{\mathrm{a}}$ & $2.87^{\mathrm{b}}$ & $4.2^{\mathrm{a}}$ & $32^{\mathrm{a}}$ \\
\hline \multirow[t]{4}{*}{$10-20$} & $\mathrm{BF}$ & $1.59^{\mathrm{b}}$ & $0.31^{\mathrm{b}}$ & $0.19^{\mathrm{ab}}$ & $0.11^{\mathrm{a}}$ & $0.92^{\mathrm{a}}$ & $2.20^{\mathrm{b}}$ & $1.47^{\mathrm{a}}$ & $3.7^{\mathrm{a}}$ & $60^{c}$ \\
\hline & $2 \mathrm{M}$ & $1.37^{\mathrm{b}}$ & $0.23^{\mathrm{a}}$ & $0.14^{\mathrm{a}}$ & $0.07^{\mathrm{a}}$ & $1.50^{\mathrm{b}}$ & $1.81^{\mathrm{b}}$ & $1.85^{\mathrm{a}}$ & $3.7^{\mathrm{a}}$ & $50^{\mathrm{b}}$ \\
\hline & $6 \mathrm{M}$ & $1.43^{\mathrm{b}}$ & $0.16^{\mathrm{a}}$ & $0.33^{\mathrm{b}}$ & $0.19^{\mathrm{b}}$ & $1.67^{c}$ & $2.11^{\mathrm{b}}$ & $1.74^{\mathrm{a}}$ & $3.9^{\mathrm{a}}$ & $55 b^{c}$ \\
\hline & $36 \mathrm{M}$ & $0.53^{\mathrm{a}}$ & $0.22^{\mathrm{a}}$ & $0.16^{\mathrm{a}}$ & $0.10^{\mathrm{a}}$ & $2.28^{c}$ & $1.01^{\mathrm{a}}$ & $2.76^{\mathrm{b}}$ & $3.8^{\mathrm{a}}$ & $27^{\mathrm{a}}$ \\
\hline
\end{tabular}


Table 2

Temporal evolution of soil chemical properties after the prescribed fire relative to pre-fire situation. Before prescribed fire (BF), two $(2 \mathrm{M})$, six $(6 \mathrm{M})$ and thirty-six $(36 \mathrm{M})$ months after prescribed fire.

\begin{tabular}{|c|c|c|c|c|c|c|c|c|c|}
\hline \multirow{3}{*}{$\begin{array}{l}\text { Chemical } \\
\text { properties }\end{array}$} & \multicolumn{9}{|c|}{ Depth } \\
\hline & \multicolumn{3}{|c|}{$0-5 \mathrm{~cm}$} & \multicolumn{3}{|c|}{$5-10 \mathrm{~cm}$} & \multicolumn{3}{|c|}{$10-20 \mathrm{~cm}$} \\
\hline & $2 \mathrm{M}$ & $6 \mathrm{M}$ & $36 \mathrm{M}$ & $2 \mathrm{M}$ & $6 \mathrm{M}$ & $36 \mathrm{M}$ & $2 \mathrm{M}$ & $6 \mathrm{M}$ & $36 \mathrm{M}$ \\
\hline SOM & + & - & + & - & - & + & + & - & + \\
\hline $\mathrm{pH}\left(\mathrm{H}_{2} \mathrm{O}\right)$ & + & + & $=$ & + & + & - & + & + & - \\
\hline P extractable & $=$ & + & + & - & + & + & - & + & + \\
\hline K extractable & - & - & - & - & - & - & - & - & - \\
\hline $\mathrm{Ca}^{2+}$ & - & - & - & - & - & - & - & - & - \\
\hline $\mathrm{Mg}^{2+}$ & - & - & - & - & - & - & - & - & - \\
\hline $\mathrm{K}^{+}$ & - & + & - & - & + & - & - & + & - \\
\hline $\mathrm{Na}^{+}$ & - & $=$ & $=$ & - & + & - & - & + & - \\
\hline SEB & - & - & - & - & + & - & - & - & - \\
\hline EA & + & - & + & + & + & + & + & + & + \\
\hline CEC & - & - & - & - & + & + & $=$ & + & + \\
\hline BS & - & + & - & - & + & - & - & - & - \\
\hline $\mathrm{Al}^{3+}$ & + & + & + & + & + & + & + & + & + \\
\hline $\mathrm{EC}$ & - & + & - & - & - & - & - & - & - \\
\hline
\end{tabular}

SOM - soil organic matter; SEB - sum exchangeable bases; EA - exchangeable acidity; CEC - cation exchangeable capacity; BS - base saturation; E C - electrical conductivity.

significantly higher $(+)$ or significantly lower $(-)$ than the pre-fire situation $(\mathrm{BF})$.

slightly higher $(+)$ or lower $(-)$ than the pre-fire situation, but not statistically significant.

as to cause organic matter oxidation. Alcañiz et al. (2014) observed an increase in SOM immediately after a prescribed fire, but a year later the organic matter content was lower than that recorded before the fire. Fire effects on soil organic matter are not yet fully known so as to precisely describe SOM quantitative and qualitative dynamics after fire (González-Pérez et al., 2004; Armas-Herrera et al., 2016).

After the fire, extractable phosphorus content tends to increase due

Table 3

Total precipitation and 6 plots mean and extreme values of runoff and soil loss, and the related indices.

\begin{tabular}{llll}
\hline Parameter & Minimum & Maximum & Average \\
\hline Total precipitation (mm) 545.3 & & & \\
Runoff (mm) & 9.8 & 19.2 & 13.0 \\
Soil loss $\left(\mathrm{g} \mathrm{m}^{-2}\right)$ & 95.8 & 276.6 & 147.3 \\
Runoff coefficient (\%) & 1.8 & 3.5 & 2.4 \\
Sediment concentration $\left(\mathrm{g} \mathrm{L}^{-1}\right)$ & 8 & 14 & 11 \\
Unitary soil loss $\left(\mathrm{g} \mathrm{m}^{-2} \mathrm{~mm}^{-1}\right)$ & 0.18 & 0.51 & 0.27 \\
\hline
\end{tabular}

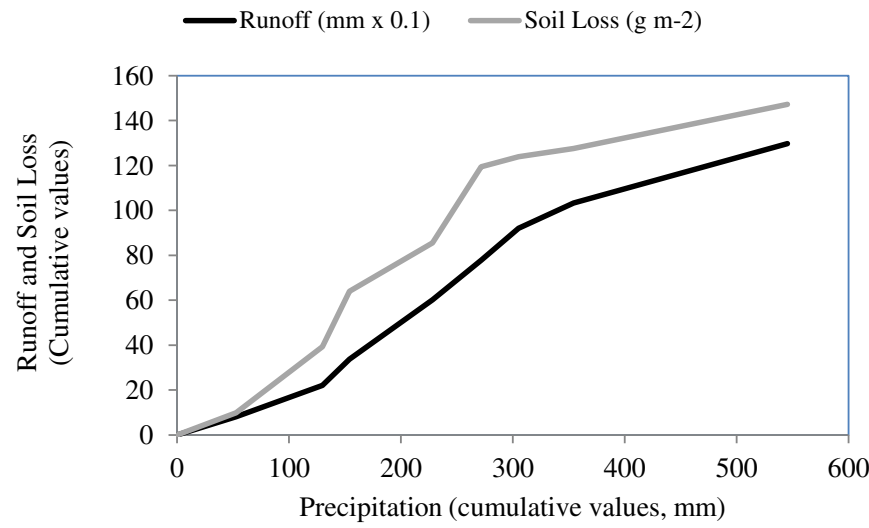

Fig. 6. Temporal evolution of runoff and soil loss throughout the experiment: average of 6 erosion plots for 14 months. to the mineralization of organic forms this element is part of, ashes from burned vegetation being also a major contribution to its increase in topsoil after fire (Huseyin, 2006). Regardless of the fire effect in phosphorus increase this and other nutrients are generally deposited on topsoil as part of ash, where they are susceptible to loss by erosion and leaching (Wienhold and Klemmedson, 1992). This may explain the reduction of soil phosphorus content found in this study two months after fire. Despite the increase of extractable phosphorus content with time, values are yet considered very low $\left(0-25 \mathrm{mg} \mathrm{kg}^{-1}\right)$ in all depths and sampling dates (Santos, 2015). Alcañiz et al. (2014) report increases in the phosphorus content after the fire passage but one year later the values were lower than those recorded before the fire. According to Certini (2005), the increase in phosphorus due to fire is ephemeral, lasting for less than a year. Arocena and Opio (2003) and Scharenbroch et al. (2012) found that extractable phosphorus content was not affected by prescribed fire, as observed in the present study in the surface layer $(0-5 \mathrm{~cm})$.

Extractable potassium decrease two and six month after the fire, as reported for phosphorus, these losses can be attributed to the processes of leaching and erosion (Fonseca et al., 2011), as well as to vegetation root uptake which fastly grew up in this period. Thirty-six months after the fire the potassium content is identical to pre-fire situation and it is

Table 4

Soil permeability of the surface soil: mean and dispersion of values of 11 samples. Averages followed by different letters differ significantly, $(\mathrm{p}<0.05$; SD - Standard Deviation).

\begin{tabular}{lllll}
\hline Statistics & Before the fire & After the fire & \\
\hline & \multicolumn{5}{l}{ Immediately } & 2 Months & 8 Months \\
\hline Parametric & & Permeability $\left(\mathrm{cm} \mathrm{h}^{-1}\right)$ & \\
Average - SD & - & - & 20 & 18 \\
Average & $22^{\mathrm{a}}$ & $14^{\mathrm{a}}$ & $113^{\mathrm{c}}$ & $36^{\mathrm{b}}$ \\
Average + SD & 51 & 30 & 206 & 54 \\
No parametric & & & & \\
Minimum & 0 & 1 & 17 & 16 \\
Median & 13 & 9 & 81 & 28 \\
Maximum & 94 & 50 & 250 & 76 \\
\hline
\end{tabular}


classified as high $\left(101-200 \mathrm{mg} \mathrm{kg}^{-1} ; 0-5 \mathrm{~cm}\right)$ and moderate (51-100 $\mathrm{mg} \mathrm{kg}^{-1}$; 5-10 and 10-20 cm) (Santos, 2015). Shakesby et al. (2015) observed that one year after prescribed fire the extractable potassium content of the soil increased compared to the pre-fire situation. In this study, however, two and thirty-six months later their content was less than the initial one. Úbeda and Outeiro (2009) verified that the potassium contents three years after fire had not recovered with respect to the initial contents, attributing this fact to the consumption of this nutrient by the emergent vegetation.

The sum of exchangeable bases (SEB) generally decreased after the fire at all depths, which would be expected, since this parameter reflects the variation of the base cations, and these also suffered reductions by fire effect, which is in agreement with Fonseca et al. (2011). The values of this parameter (SEB) are considered low (LQARS (Laboratório Químico Agrícola Rebelo da Silva), 2006). As base cations are very soluble, the main losses are associated with soil erosion and leaching processes. The cation exchangeable capacity (CEC) shows small variations over time, without significant differences, following closely the variations on soil organic matter, in agreement with other studies (e.g., Huseyin, 2006; Inbar et al., 2014), which refer changes in CEC and organic matter in the same sense. The variation of the exchangeable acidity values had similar behaviour to the exchangeable aluminum content and always decreased during the experimental period.

Two and six months after the prescribed fire, $\mathrm{pH}$ values are significantly higher than those observed before fire, a tendency also observed by Scharenbroch et al. (2012). The increase in $\mathrm{pH}$ is related to the presence of carbonates, base cations and oxides in the ash formed and deposited in the soil during the fire (Huseyin, 2006). Thirty-six months after the fire the $\mathrm{pH}$ values are similar to those recorded in the reference situation, meaning that the impact caused by the fire in the soil reaction is no longer verified. According to Mataix-Solera and Guerrero (2007), the recovery time of the initial $\mathrm{pH}$ is variable and depends on the time that ashes remain in the soil. The response of the electrical conductivity to the passage of the fire resulted in a slight reduction, a fact that is generally not observed, since the presence of the ashes contributes to an increase of salts in solution (Huseyin, 2006). Overall, effects of fire on chemical soil properties were described by several authors (e.g., Úbeda and Outeiro, 2009; Fonseca et al., 2011; Inbar et al., 2014; Armas-Herrera et al., 2016), yet with trends in temporal changes that are not always similar to those found in this study, which might be due to a large set of local factors as post-fire rainfalls, fire severity and intensity, litter thickness and moisture content, not always comparable in the referred studies.

The evaluation period of runoff and soil loss was abnormally dry and with a very different distribution from the normal pattern (rainfall in the summer months and a winter without precipitation) (Fig. 4). Considering that precipitation is a fundamental erosion factor, the erosive response obtained might be taken as representative of a potential minimum for the conditions under study. The annual erosion rate, equivalent to $1.3 \mathrm{Mg} \mathrm{ha}^{-1}$, is lower than the soil loss tolerance indicated for shallow soils of non-renewable substrate (2.2 $\mathrm{Mg} \mathrm{ha}^{-1}$ year $^{-1}$; Arnoldus, 1977), although approaching the value of $1.4 \mathrm{Mg} \mathrm{ha}^{-1}$ year $^{-1}$, which is in process of acceptance as soil loss tolerance in the European space (Verheijen et al., 2009). It is also lower than that recorded in plots of similar size installed in the early years of a forest stand, with similar surface conditions for adventitious vegetation cover (Figueiredo et al., 2012). In burned forest and shrublands areas, the records are generally higher (Thomas et al., 1999; Andreu et al., 2001; Pardini et al., 2004; Gimeno-García et al., 2007; Shakesby, 2011). Interpretation in the same direction is valid for the average annual runoff $(10.3 \mathrm{~mm})$. Despite soil loss values obtained in this work are low, since the study area was established on shallow soils (Leptosols), these losses might be representative and contribute gradually to the exposure of bedrock; indeed, this is already observed in neighbouring areas. The very low annual precipitation justifies, at first approach, these values since, taking the unit soil loss calculated for the experimental period as an estimator $\left(0.27 \mathrm{~g} \mathrm{~m}^{-2} \mathrm{~mm}^{-1}\right)$, a loss of $2.3 \mathrm{Mg} \mathrm{ha}^{-1}$ is obtained in a year with normal climatic conditions. In addition, other factors not explored in the analysis of the results may be contributing to low soil loss as the case of the high soil stoniness in the area, a situation similar to that of other areas studied by the authors in the NE of Portugal (Figueiredo, 2001; Figueiredo et al., 2012). The temporal evolution of soil loss and runoff follows an already known pattern, experimentally verified in areas of bare or sparsely vegetated soil (Figueiredo et al., 2012). The sigmoid shape of the soil loss response curve to cumulative rainfall was explained by Figueiredo et al. (2009) as the result of selective erosion of fine particles in soils covered by surface rock fragments, and the descriptive model presented by these authors outputs a faster decline in soil loss rate as surface cover by rock fragments becomes higher, and this corresponds to the situation prevailing in the experimental area.

The dispersion of permeability values corresponds to the typical situation observed in this soil property (Hillel, 1998). The decrease of the permeability immediately after fire with respect to pre-fire situation is widely referenced in literature, and in general it is attributed to soil hydrophobicity generated by lipid compounds released from burnt plant material, whose persistence in the soil is very variable, depending on fire severity and environmental conditions after fire (Imeson et al., 1992; Hubbert et al., 2006; Are et al., 2009; Woods and Balfour, 2010). The high mean permeability values, and even the median, show that this effect was no more evident in the study area two months after fire. For this, may have contributed the abnormally high soil moisture conditions in this period of the year (late spring-early summer. The temporal evolution of permeability after the short term effects of fire on hydrophobicity can be also explained by soil structural rearrangements affecting biopores functionality (Figueiredo et al., 2013).

The direct and indirect effects of fire were often studied in soil surface (e.g., Arocena and Opio, 2003; Huseyin, 2006; Thomaz and Fachin, 2014; Meira-Castro et al., 2015; Armas-Herrera et al., 2016; Aznar et al., 2016), but some works showed that these effects reach deeper soil layers, at least down to $30 \mathrm{~cm}$ (Fonseca et al., 2011; Dennis et al., 2013; Heydari et al., 2017). The present work is in agreement with the results presented by the former authors, contributing to reinforce the idea that more attention should be given to the direct and indirect effects of fire at deeper depths. The variations observed in the chemical and physical properties of the first $20 \mathrm{~cm}$ topsoil can be related to the heating of the soil (Dennis et al., 2013) and the production of hydrophobic substances (e.g., Keizer et al., 2008), which in turn cause changes in the biological activity (e.g., Guerrero et al., 2005), hydraulic conductivity (e.g., Imeson et al., 1992; Fonseca et al., 2011), chemical transformations occurring in the soil (e.g., Heydari et al., 2017), and erosion and leaching processes (e.g., Cancelo-González et al., 2015). In the present study, soil permeability was high and very high in all measurement campaigns performed. On the other hand, runoff coefficient calculated from erosion plot data shows an average of about $2.4 \%$, meaning that most rainfall infiltrates in the soil and redistributes easily through the uppermost layers. Therefore, solute transfer downwards is restricted only by nutrient immobilization processes, either organic or in inorganic. Therefore, leaching could easily occur following rainfall events. This may have contributed to significant changes in soil chemical properties found in deeper sampled layers (5-10 and 10-20 cm) that, by no means, could have been affected by direct heating during fire passage.

\section{Conclusions}

Prescribed fire is a commonly recommended forest management practice aiming at controlling fuel accumulation in forest stands understory or in the shrub covered surroundings, due to the lower economic cost compared to other vegetation management techniques. Such control is required to reduce wildfire risk. This is important in Mediterranean mountain areas because weather prevailing during the 
dry summer months generates high potential hazardous conditions for ignition and, therefore, fire occurrence and propagation mostly depend on fuel amount and continuity. On the other hand, mountain areas show an increasingly larger extent of unmanaged areas, where fuel stocks grow uncontrolled, increasing fire hazard on the neighbouring managed woodlands.

By definition, prescribed fires have negligible or low severity, meaning that the effects of fire on soils, mostly studied after severe wildfires, are not actually expected. The research conducted in a scrubland, in Montesinho Natural Park, Portugal, where prescribed fire was applied as part of the management plan of pine forest stands growing in this area, showed that a period of thirty-six months was not enough to cancel out the effects of an effectively low severity prescribed fire on the soil chemical properties. In fact, thirty-six months after the fire, significant effects persist on some soil properties, namely on sum of exchangeable bases, exchangeable aluminum and on phosphorus and potassium contents. These results, especially regarding the soil layers from 5 to $20 \mathrm{~cm}$ soil depth may help deconstructing the idea that the effects of fire are restricted to the uppermost soil surface layer, as far as dynamic processes as leaching are taken into account in results interpretations. Nevertheless, the recovery of most soil chemical properties, so as to reach the levels prevailing before the prescribed fire, was faster in the surface layer $(0-5 \mathrm{~cm})$ and this is understood as a result of the biological activity and the weathering processes that are more intense at surface than in deeper topsoil layers.

Although the absolute values reported in relation to the variables indicative of soil physical degradation (permeability, runoff and soil loss) by fire effect in the study area, are not expressive, they elucidate however on the complexity of the responses in the hydrological and soil processes in these conditions. In addition, and especially with regard to water erosion, consideration should be given to the fact that the starting condition corresponds to shallow soils, already degraded in their capacity to support a significant vegetation cover capable of soil protection. The observed sigmoid shape of the erosion response curve to cumulative precipitation along the monitoring period shows that the initial soil loss rate, after fire, rapidly declines to much lower values and this is explained for the most by shortage of available fines to be entrained by surface runoff. In marginal or degraded areas as these, having high surface stoniness, measured soil loss is not high, but the fines shortage at surface raises their importance in a so fragile environment, as a soil fertility background necessary for vegetation recovery and its further feedback effects in soil protection.

The research carried out also allowed an insight on soil recovery rates in burnt areas after light severity fire. Even though recovery is ongoing, and faster in the uppermost soil layer, after thirty-six months the $20 \mathrm{~cm}$ topsoil did not yet reach the prior to fire condition. As compared to severe wildfires, prescribed fires have far lower impacts on soil, and this study did not actually focus on the widely proven assets of this forest management practice. On the contrary, it calls the attention to the high fragility of marginal mountain areas, where light environmental stresses cause significant impacts that may stand for long, as slow recovery rates leave them exposed to further stresses.

\section{References}

Agroconsultores and Coba, 1991. Carta dos Solos do Nordeste de Portugal. UTAD, Vila Real.

Alcañiz, M., Úbeda, X., Outeiro, L., Farrés, M., 2014. Effects of a prescribed fire in a calcareous soil (Montgrí Massif, NE Spain). Flamma 5 (1), 45-48.

Alcañiz, M., Outeiro, L., Francos, M., Farguell, J., Úbeda, X., 2016. Long-term dynamics of soil chemical properties after a prescribed fire in a Mediterranean forest (Montgrí Massif, Catalonia, Spain). Sci. Total Environ. 572, 1329-1335.

Andreu, V., Imeson, A.C., Rubio, J.L., 2001. Temporal changes in soil aggregates and water erosion after a wildfire in a Mediterranean pine forest. Catena 44, 69-84.

Are, K.S., Oluwatosin, G.A., Adeyolanu, O.D., Oke, A.O., 2009. Slash and burn effect on soil quality of an Alfisol: soil physical properties. Soil Tillage Res. 103, 4-10.

Armas-Herrera, C.M., Martí, C., Badía, D., Ortiz-Perpiñá, O., Girona-García, A., Porta, J., 2016. Immediate effects of prescribed burning in the Central Pyrenees on the amount and stability of topsoil organic matter. Catena 147, 238-244.
Arnoldus, H.M.J., 1977. Methodology used to determine the maximum potential average annual soil loss due to sheet and rill erosion in Morocco. In: Assessing Soil Degradation. FAO Soils Bulletin n 34 FAO, Rome, Italy.

Arocena, J.M., Opio, C., 2003. Prescribed fire-induced changes in properties of subborealforest soils. Geoderma 113, 1-16.

Aznar, J.M., González-Pérez, J.A., Badía, D., Martí, C., 2016. At what depth are the properties of a gypseous forest topsoil affected by burning? Land Degrad. Dev. 27 (5), 1344-1353.

Bento-Gonçalves, A., Vieira, A., Úbeda, X., Martin, D., 2012. Fire and soils: key concepts and recent advances. Geoderma 191, 3-13.

Bompastor, A., Figueiredo, T., Fonseca, F., 2009. Matos do Parque Natural de Montesinho, NE de Portugal - produção de serviços ecossistémicos. In: Proceedings of $15^{\circ}$ Congresso da APDR (6-11 June 2009, Cidade da Praia, Cabo Verde). Unipiaget, pp. 339-364.

Brooks, M., Lusk, M., 2009. Fire Management and Invasive Plants: A Handbook. United States Fish and Wildlife Service, Arlington Virginia (27 pp.).

Cancelo-González, J., Prieto, D.M., Díaz-Fierros, F., Barral, M.T., 2015. Fe and Al leaching in soils under laboratory controlled burns. Span. J. Soil Sci. 5 (1), 82-97.

Certini, G., 2005. Effects of fire on properties of forest soils: a review. Oecologia 143, $1-10$.

FAO/UNESCO, 1988. Soil Map of the World, Revised Legend, Amended 4th Draft. FAO, Roma.

Fernandes, P., Botelho, H., 2004. Analysis of the prescribed burning practice in the pine forest of northwestern Portugal. J. Environ. Manag. 70, 15-26.

Fernandes, P.M., Loureiro, C., 2010. Handbook to plan and use prescribed burning in Europe. In: Integrated Project FIRE PARADOX. European Commission.

Figueiredo, T., 2001. Pedregosidade e Erosão Hídrica dos Solos em Trás-os-Montes: contributo para a interpretação de registos em vinhas ao alto na Região do Douro. (PhD thesis) Universidade de Trás-os-Montes e Alto Douro, Vila Real, Portugal.

Figueiredo, T., 2002. Uma panorâmica sobre os recursos pedológicos do Nordeste Transmontano. In: Proceedings of II Seminário sobre Recursos Naturais do Nordeste Transmontano (November 2011, Bragança, Portugal). Escola Superior de Educação de Bragança.

Figueiredo, T., Fonseca, F., Martins, A., 2012. Soil loss and runoff in young forest stands as affected by site preparation technique: a study in NE Portugal. Eur. J. For. Res. $131,1747-1760$.

Figueiredo, T., Fonseca, F., Queirós, A., 2013. Efeitos do fogo na erosão do solo em áreas de matos: resultados de um ano de ensaio no Parque Natural de Montesinho. In: Bento-Gonçalves, A., Vieira, A. (Eds.), Grandes incêndios florestais, erosão, degradação e medidas de recuperação dos solos. NIGP - Núcleo de Investigação em Geografia e Planeamento Universidade do Minho, Portugal.

Fonseca, F., Leite, M., Figueiredo, T., 2011. Soil properties in burned and unburned Mediterranean shrublands of Montesinho Natural Park, Northeast Portugal. In: Gonçalves, A.B., Vieira, A. (Eds.), Fire Effects on Soil Properties. University of Minho, Guimarães, Portugal.

Fonseca, F., Figueiredo, T., Bompastor, M.A., 2012. Carbon storage in shrub communities of Montesinho Natural Park in northeast of Portugal. Agrofor. Syst. 86, 463-475.

Francos, M., Pereira, P., Alcañiz, M., Mataix-Solera, J., Úbeda, X., 2016. Impact of an intense rainfall event on soil properties following a wildfire in a Mediterranean environment (North-East Spain). Sci. Total Environ. 572, 1353-1362.

Gimeno-García, E., Andreu, V., Rubio, J.L., 2007. Influence of vegetation recovery on water erosion at short and medium-term after experimental fires in a Mediterranean shrubland. Catena 69, 150-160.

González-Pérez, J.A., González-Vila, F.J., Almendros, G., Knicker, H., 2004. The effect of fire on soil organic matter-a review. Environ. Int. 30, 855-870.

Guerrero, C., Mataix-Solera, J., Gómez, I., García-Orenes, F., Jordán, M.M., 2005. Microbial recolonization and chemical changes in a soil heated at different temperatures. Int. J. Wildland Fire 14, 385-400.

Heydari, M., Rostamy, A., Najafi, F., Dey, D.C., 2017. Effect of fire severity on physical and biochemical soil properties in Zagros oak (Quercus brantii Lindl.) forests in Iran. J. For. Res. 28 (1), 95-104.

Hillel, D., 1998. Environmental Soil Physics. Academic Press, San Diego, USA.

Hubbert, K.R., Preisler, H.K., Wohlgemuth, P.M., Graham, R.C., Narog, M.G., 2006. Prescribed burning effects on soil physical properties and soil water repellency in a steep chaparral watershed, southern California, USA. Geoderma 130, 284-298.

Hungerford, R.D., 1996. Soils, Fire in Ecosystem Management Notes: Unit II-I. USDA Forest Service, National Advanced Resource Technology Center, Marana, Arizona.

Huseyin, E., 2006. Effect of forest fire on some physical, chemical and biological properties of soil in Çanakkale. Int. J. Agric. Biol. 8 (1), 102-106.

Imeson, A.C., Verstrate, J.M., van Mulligen, E.J., Sevink, J., 1992. The effects of fire and water repellence on infiltration and runoff under Mediterranean type forest. Catena 19, 345-361.

Inbar, A., Lado, M., Sternberg, M., Tenau, H., Ben-Hur, M., 2014. Forest fire effects on soil chemical and physicochemical properties, infiltration, runoff, and erosion in a semiarid Mediterranean region. Geoderma 221 (222), 13-138.

IPB/ICN, 2007. Plano de Ordenamento do Parque Natural de Montesinho Caracterização, Bragança.

IPMA (Instituto Português do Mar e da Atmosfera), 2016. Boletins climatológicos mensais. https://www.ipma.pt/pt/publicacoes/boletins.

Jones, J.B., 2001. Laboratory Guide for Conducting Soil Tests and Plant Analysis. CRC Press, Boca Raton.

José, S., 2009. Agroforestry for ecosystems services and environmental benefits: an overview. Agrofor. Syst. 76, 1-10

Keizer, J.J., Doerr, S.H., Malvar, M.C., Prats, S.A., Ferreira, R.S.V., Oñate, M.G., Coelho, C.O.A., Ferreira, A.J.D., 2008. Temporal variation in topsoil water repellency in two recently burnt eucalypt stands in north-central Portugal. Catena 74 (3), 192-204. 
LQARS (Laboratório Químico Agrícola Rebelo da Silva), 2006. Manual de Fertilização das Culturas. Instituto Nacional de Investigação Agrária e das Pescas, Lisboa.

de Luís, M., García-Cano, M.F., Cortina, J., Raventós, J., González-Hidalgo, J.C., Sánchez, J.R., 2001. Climatic trends, disturbances and short-term vegetation: dynamics in a Mediterranean shrubland. For. Ecol. Manag. 147, 25-37.

Mataix-Solera, J., Guerrero, C., 2007. Efectos de los incendios forestales sobre las propiedades edáficas. In: Incendios forestales, suelos y erosión hídrica (Mataix- Solera, J. coord.), Alcoi, Edit. Caja Mediterráneo CEMACAM, pp. 5-40.

Meira-Castro, A., Shakesby, R.A., Espinha Marques, J., Doerr, S.H., Meixedo, J.P., Teixeira, J., Chamine, H.I., 2015. Effects of prescribed fire on surface soil in a Pinus pinaster plantation, northern Portugal. Environ. Earth Sci. 73, 3011-3018.

Pardini, G., Gispert, M., Dunjó, G., 2004. Relative influence of wildfire on soil properties and erosion processes in different Mediterranean environments in NE Spain. Sci. Total Environ. 328, 237-246.

Parker, T.J., Karen, M.C., Mathiasen, R.L., 2006. Interactions among fire, insects and pathogens in coniferous forests of the interior western United States and Canada. Agric. For. Entomol. 8, 167-189.

Pausas, J.G., Keeley, J.E., 2009. A burning story: the role of fire in the history of life. Bioscience 59, 593-601.

Pausas, J.G., Llovet, J., Rodrigo, A., Vallejo, R., 2008. Are wildfires a disaster in the Mediterranean basin? - a review. Int. J. Wildland Fire 17, 713-723.

Rashid, G.H., 1987. Effects of fire on soil carbon and nitrogen in a Mediterranean oak forest of Algeria. Plant Soil 103, 89-93.

Santos, J.Q., 2015. Fertilização, Fundamentos agroambientais da utilização dos adubos e correctivos. Publindústria, Lisboa.

Scharenbroch, B.C., Nix, B., Jacobs, K.A., Bowles, M.L., 2012. Two decades of low-severity prescribed fire increases soil nutrient availability in a Midwestern, USA oak
(Quercus) forest. Geoderma 183 and 184, 80-91.

Shakesby, R.A., 2011. Post-wildfire soil erosion in the Mediterranean: review and future research directions. Earth Sci. Rev. 105, 71-100.

Shakesby, R.A., Bento, C.P.M., Ferreira, C.S.S., Ferreira, A.J.D., Stoof, C.R., Urbanek, E., et al., 2015. Impacts of prescribed fire on soil loss and soil quality: an assessment based on an experimentally burned catchment in central Portugal. Catena 128, 278-293.

Thomas, A.D., Walsh, R.P.D., Shakesby, R.A., 1999. Nutrient losses in eroded sediment after fire in eucalyptus and pine forests in the Mediterranean environment of northern Portugal. Catena 36, 283-302.

Thomaz, E.L., Fachin, P.A., 2014. Effects of heating on soil physical properties by using realistic peak temperature gradients. Geoderma 230-231, 243-249.

Úbeda, X., Outeiro, L., 2009. Physical and chemical effects of fire on soil. In: Cerdà, A., Robichaud, P.R. (Eds.), Fire Effects on Soils and Restoration Strategies. Science Publishers, Enfield, NH, pp. 105-133.

Verheijen, F.G.A., Jones, R.J.A., Rickson, R.J., Smith, C.J., 2009. Tolerable versus actual soil erosion rates in Europe. Earth-Sci. Rev. 94, 23-38.

Wasserman, T.N., 2015. Wildlife and fire: impacts of wildfire and prescribed fire on wildlife and habitats in southwestern coniferous forests. In: ERI Working Paper No. 36. Ecological Restoration Institute and Southwest Fire Science Consortium. Northern Arizona University ( 9 p.).

Wienhold, B.J., Klemmedson, J.O., 1992. Effect of prescribed fire on nitrogen and phosphorus in Arizona chaoarral soil-plant systems. Arid Soil Res. Rehabil. 6, 285-296.

Woods, S.W., Balfour, V.N., 2010. The effects of soil texture and ash thickness on the postfire hydrological response from ash-covered soils. J. Hydrol. 393, 274-286. 